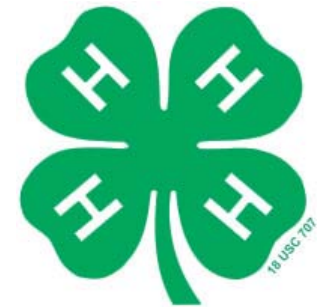

\title{
Introducing 4-H Youth Development ${ }^{1}$
}

Marilyn N. Norman and Joy C. Jordan ${ }^{2}$

Youth development has been defined as an ongoing process through which young people attempt to meet their needs and to develop the competencies they perceive as necessary for survival and transition to adulthood. Positive Youth Development is development that is positive and productive for both youth and their communities.

Youth development refers to the development of the whole person and is not focused on a single attribute, skill, or characteristic, but rather the mastery of competencies needed for happy and productive adulthood. Positive youth development occurs from an intentional process that promotes positive outcomes for young people by providing opportunities, choices, relationships, and the support necessary for youth to fully participate.

Youth development is the work of youth. Adults cannot do this work for them. But caring, knowledgeable, and skilled adults can contribute to the success of young people as they grow and develop. Adults do this by providing environments for youth that are safe and nurturing and by expanding opportunities for experiences that will help young people develop skills they need for adulthood. Youth development professionals guide the community in providing these experiences.

In recent years, non-formal, out-of-school programs for youth have become recognized as key avenues for delivering these environments and opportunities. Universities and youth focused organizations have identified the research and knowledge base that supports effective programming for youth development, as well as the effective principles and practices in delivering these programs. Course work leading toward a graduate degree in youth development is now available from several universities and university consortiums across the United States. There is recognition of the need for professionals in the field and support for professional staff development throughout the career cycle. A vocabulary to advocate for the work is in place.

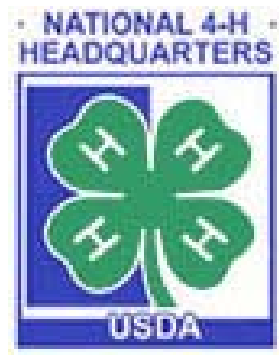

4-H Youth Development is the non-formal, educational program for youth of the Cooperative State Research, Education and

\footnotetext{
${ }^{1}$ This document is 4-H S FS101.2, one of a series of the Florida 4-H Program, Florida Cooperative Extension Service, Institute of Food and Agricultural Sciences, University of Florida. This material is based upon work supported by the Cooperative Research, Education, and Extension Service, US Department of Agriculture, and K-State Research and Extension, Kansas State University, under special project number 99-EYAR-1-0747. This 4-H 101 Handbook was developed by the 4-H 101 Design Team chaired by Andrea Hutson, USDA/Army Youth Development Project, CSREES/Virginia Tech University. It was adapted for Florida by Marilyn N. Norman and Joy C. Jordan, State 4-H Program. Published May 2006. Please visit the 4-H Website at http://4h.ifas.ufl.edu.

${ }^{2}$ Marilyn Norman, Associate Professor in Family Youth and Community Sciences, and State 4-H Program Leader, and Joy C. Jordan, Associate Professor in Family, Youth and Community Sciences, Institute of Food and Agricultural Sciences, University of Florida, Gainesville.
} 
Extension Service of the U.S. Department of Agriculture. It has gained a national reputation for its work with youth throughout the past century. 4-H is unique in the non-formal youth development field because it is a partner with the land grant university system and has access to the most current knowledge and research provided by those universities related to youth development. In addition, 4-H staff and Cooperative Extension Offices are located in almost every county in the U.S. and are connected through an extensive electronic network that assures access to the most current developments from the field. This blending of research and field knowledge provides noteworthy support for the 4-H Youth Development Professional.

Agencies who have partnered with 4-H in recent years have cited the following strengths that 4- $\mathrm{H}$ brings to the partnership:

- 4-H is a nationally recognized effective youth development education program.

- Cooperative Extension/4-H has a strong local, county, state, and national infrastructure and international support.

- Cooperative Extension/4-H outreach service opportunities support communities and community service efforts.

- Cooperative Extension/4-H research-based youth curriculum materials support the mission of other youth organizations.

- Cooperative Extension/4-H staff are youth development professionals trained in adult education and youth programming and are capable and accessible resources.

- Cooperative Extension/4-H has a record of successful partnerships with youth serving organizations including worldwide youth programs within the military.

\section{4-H Professional Research and Knowledge Base (4hPRK)}

Since its inception in 1985 and through subsequent updates, the 4-H Professional
Research and Knowledge Base (4hprk) has come to be the foundation for the 4-H youth development profession. A revision in 2004 creating the 4-H PRKC model provides the road map for the 4-H youth development workforce.

The most current and comprehensive research and knowledge representing the field of $4-\mathrm{H}$ youth development, has been compiled in this study. This study identifies the current and emerging competencies that are essential to conducting 4-H youth development programs. The results of the study are key resources for:

- Individuals preparing for a career in the field of youth development

- Individuals just entering the 4-H workforce or returning to $4-\mathrm{H}$

- Designing job descriptions or hiring new youth workers

- Designing training and learning experiences for 4-H educators and volunteer staff

- Building individual learning plans or performance standards

- Focusing on strategies critical to attracting, developing and retaining an outstanding, diverse 4-H workforce

- Adding value to individual career development

- Professional association initiatives

- Increasing research and evaluation efforts for 4-H youth development

The six domains of youth development professional knowledge and competencies are:

- Youth Development

- Youth Program Development

- Volunteerism

- Equity, Access and Opportunity

- Partnerships

- Organizational Systems

These represent the areas for staff development and training for Florida 4-H Youth Professionals. For a more comprehensive resource refer to the complete document 4-H Professional Research, Knowledge and Competencies, 2004, located at the state website or National 4-H Headquarters, Cooperative State Research Education and Extension Service, USDA. 